Cipango
Cipango

Hors-série | 2008

Autour du Genji monogatari

\title{
Quelques éléments de la vie à l'époque du Genji
}

Elements of the life at the time of Genji

\section{(2) OpenEdition}

1 Journals

Édition électronique

URL : https://journals.openedition.org/cipango/801

DOI : 10.4000/cipango.801

ISSN : 2260-7706

Éditeur

INALCO

\section{Édition imprimée}

Date de publication : 1 janvier 2008

Pagination : 183

ISBN : 978-2-85831-170-5

ISSN : 1164-5857

Référence électronique

"Quelques éléments de la vie à l'époque du Genji », Cipango [En ligne], Hors-série | 2008, mis en ligne le 27 septembre 2012, consulté le 30 juin 2021. URL : http://journals.openedition.org/cipango/801 ;

DOI : https://doi.org/10.4000/cipango.801

Ce document a été généré automatiquement le 30 juin 2021.

\section{(c) (7) \&}

Cipango est mis à disposition selon les termes de la Licence Creative Commons Attribution - Pas d'Utilisation Commerciale 4.0 International. 


\section{Quelques éléments de la vie à l'époque du Genji}

Elements of the life at the time of Genji

1 Le roman de Murasaki Shikibu, comme la plupart des textes classiques, ne décrit pas, mais suggère. Très efficace pour évoquer la psychologie des personnages, cette écriture pose des problèmes d'ordre référentiel pour un lecteur contemporain qui ne partage pas la réalité de l'époque. Deux historiennes se sont attelées à la tâche pour combler ici ces lacunes : Marie Maurin (http://cipango.revues.org/601) présente le palais impérial situé dans la perspective de la capitale, et s'interroge également sur les valeurs symboliques du paulownia ( $k$ iri 桐) sous le nom duquel sont identifiés les parents du héros, l'empereur Kiritsubo et sa favorite, la dame de l'atour.

2 L'article de Charlotte von Verschuer (http://cipango.revues.org/1029), consacré aux vêtements, nous aide à nous représenter les personnages aussi bien dans leur intimité que sur la scène publique. Rappelons à ce propos que les tenues dans cette société rigoureusement codifiée constituaient un des éléments identitaires majeurs. L'article pointe également l'anachronisme des commentateurs qui projettent depuis l'époque médiévale l'image de silhouettes rigides (kowa shōzoku) sur la réalité de l'époque de ce roman, où prévalaient apparemment les tenues en lignes douces.

Des vêtements dans le Roman du Genji, il en est aussi question dans l'article de Takeda Sachiko (http://cipango.revues.org/605), spécialiste des costumes dans la période antique, mais du point de vue de "la féminité». Sa lecture relève de l'approche culturaliste et tend à évaluer une réalité historique à partir de valeurs morales. Nous ne partageons pas nécessairement toutes ses conclusions, mais il nous a paru intéressant de donner un aperçu d'un type de recherches auquel le Roman du Genji donne également lieu.

4 Francine Hérail (http://cipango.revues.org/607), quant à elle, nous confronte à la réalité socio-économique de l'époque, loin du faste de la cour de Heian, à travers une présentation complète des gouverneurs de province (zuryō), richement illustrée par deux traductions de documents des $\mathrm{x}^{\mathrm{e}}$ et $\mathrm{xI}^{\mathrm{e}}$ siècles. Nous voyons évoluer ainsi des personnages qui représentent l'un des rouages essentiels de la société à laquelle 
appartenait notre romancière, et ce n'est donc pas un hasard si certaines parmi les principaux protagonistes du roman sont, précisément, issus de ce milieu.

\section{RÉSUMÉS}

Introduction aux articles de M. Maurin, C. von Verschuer, S. Takeda et F. Hérail qui s'attachent à éclairer divers éléments du Genji tels que le palais impérial, les vêtements ou les réalités socioéconomiques décrits dans le roman.

Introduction to M. Maurin, C. von Verschuer, S. Takeda and F. Hérail's studies that highlight various aspects depicted in the Genji, such as the Imperial palace, clothing or socio-economic realities.

\section{INDEX}

Mots-clés : Dit du Genji, Genji monogatari, mœurs et coutumes, Murasaki Shikibu (v. 973-v. 1014 ou 1025)

キーワード : Genji monogatari 源氏物語, fūshū 風習, Murasaki Shikibu 紫式部 (v. 973-v. 1014 ou 1025), Heian jidai 平安時代 (794-1185), jinruigaku 人類学, bijutsushi 美術史, bungaku 文学

Keywords : Genji monogatari, Heian, Murasaki Shikibu (v. 973-v. 1014 or 1025), Anthropology 